Article

\title{
Receiving Country Investments and Acquisitions: How Migrants Negotiate the Adaptation to Their Destination
}

\author{
Neli Demireva \\ Department of Sociology, Essex University, CO4 3SQ, Colchester, UK; E-Mail: nvdem@essex.ac.uk
}

Submitted: 10 July 2019 | Accepted: 5 September 2019 | Published: 7 November 2019

\begin{abstract}
This article looks at the adaptation patterns of EU migrants-Bulgarian, Romanian, Italian and Spanish-in European markets, and uses several interviews of overseas non-EU migrants in the UK and Germany. The interaction of migrants with the receiving context is being considered. Drawing on several interviews with actual migrants and recruitment agents collected in the GEMM (Growth, Equal Opportunities, Migration and Markets) project in four major immigrant societies (Germany, UK, Spain and Italy), this article focuses on the receiving country acquisitions that facilitate the adaptation of migrants along their journeys. EU migrants have very different adaptation strategies to non-EU migrants, and this article comments on the differences observed as well as on the differences between them according to skill levels. Migrant adaptation challenges are acknowledged and studied dynamically. Thus, this unique data brings forward a multi-layered picture of the migrant adaptation process in Europe.
\end{abstract}

\section{Keywords}

adaptation; EU migrants; migrant motivations; non-EU migrants; receiving society; skills

\section{Issue}

This article is part of the issue "The Lived Experiences of Migration: Individual Strategies, Institutional Settings and Destination Effects in the European Mobility Process" edited by Neli Demireva (University of Essex, UK) and Fabio Quassoli (University of Milano-Bicocca, Italy).

(C) 2019 by the author; licensee Cogitatio (Lisbon, Portugal). This article is licensed under a Creative Commons Attribution 4.0 International License (CC BY).

\section{Introduction}

European receiving societies have experienced a huge rise in migration scepticism calling the migration governance and the successful operation and implementation of migration policies into question. In particular, fears have been voiced that EU and non-EU migrants, encouraged by generous welfare regimes are similarly uncommitted to integration and fail in their adaptation efforts (Kaufmann \& Harris, 2015). Successive European governments have tightened their migration schemes to favour "net contributors," defined as migrants who bring a range of fiscal benefits while having good social integration prospects (OECD, 2017). Yet, little is known about the different integration strategies of migrants and the numerous challenges they face on the path to adaptation. Indeed, integration is often perceived as the successful outcome of the overall adaptation of the migrant and the final stages of their journey (see Koopmans, 2016).
Before various European receiving societies prepare to further punish migrants who fail to 'invest' in their destination, it is important to hear migrant voices and understand better the barriers that they may face in implementing an adaptation strategy. Using a unique dataset of qualitative interviews with migrants of various nationalities, different skill levels, and a variety of motivations in four major migration destinations in EuropeGermany, the UK, Italy and Spain-this article is wellplaced to bring some innovative perspectives to the fore and challenge well-established migration tropes. The respondents in the interviews gathered by the GEMM (Growth, Equal Opportunities, Migration and Markets) study have employed a variety of adaptation techniques (for example, several other contributions in this thematic issue focus on social ties and acculturation), but the focus of this article are investments in human capital, degree translation and citizenship that allow migrants to navigate the mainstream receiving context. 


\section{Thematic Framework}

Migrants are generally considered to arrive with knowledge and skillsets which are not particularly tailored to the needs of employers of the receiving society. In addition, they may not be fully prepared to be embedded in the social milieu in their destination (Friedberg, 2000). Overtime, they are expected to have made several investments in the destination country that further their integration efforts, which are the focus of this article.

Migrants are not likely to make uniform investments in the destination country. The acquisition and adaptation strategies they adopt will depend upon their own motivations and time horizons, the challenges they face in the migration journey, the different skillsets they bring, and finally the professional constraints imposed by the occupations and industries in which they are embedded.

The literature hypothesizes that there are large differences in adaptation strategies of migrants according to their motivations, with sharp distinction between economic migrants and migrants who arrive for reasons of family reunification and study. While some studies claim that the initial motivation leaves a lasting impact (Cangiano, 2015; Kogan, Kalter, Liebau, \& Cohen, 2011), some other studies claim that for many migrants, especially within-European migrants a variety of reasons can be observed (Corluy, Marx, \& Verbist, 2011). Due to our sampling frame, we primarily observe economic migrants. Economic migrants are considered to have made the conscious choice to migrate to a specific country with the purpose of work and generally match the economic conditions in the receiving country well. In many cases, their adaptation strategies are thought to be clearly defined and shaped by interaction with different receiving society institutions (Duleep \& Regets, 1999). This article argues however that there might be significant differences depending on the migrant skillset.

Apart from having different starting points, migrants with varying qualification are also hypothesized to have differing integration patterns (Kogan \& Shen, 2019; Kogan, Shen, \& Siegert, 2018). Economic migrants who come with an already secured job or with strong intention to work can have incentives to improve their position which non-economic migrants or unskilled migrants may not share (Cortes, 2004a). At the same time, a short term time horizon in the host country may encourage circular migration and in practice might mean having less time to invest in language courses and knowledge about the receiving society (Luthra, Platt, \& Salamońska, 2016). The interviews collected during the GEMM project allow us to get a unique glimpse in the strategic decisionmaking process of migrants.

\subsection{Human Capital Acquisitions: Language and the Ethnic Niches}

One of the most important receiving society acquisitions is language. Speaking the language of the destination country well is often considered crucial for sustained integration and is a main requirement for finding good employment, making use of public services and becoming part of the social fabric of the destination. It therefore brings considerable returns in the social and economic sphere (Campbell, 2014; Cebulla et al., 2010; Cheung \& Phillimore, 2013; Cortes, 2004b; de Vroome \& van Tubergen, 2010; Dustmann, Frattini, \& Halls, 2010).

Economic migrants unlike family migrants may not receive state-funded and institutional support in the form of integration courses, language courses and career support (Bevelander \& Pendakur, 2014; Cangiano, 2015; de Vroome \& van Tubergen, 2010). It is quite likely however that already highly-skilled individuals will engage in the positive practice of acquiring further human capital (Duleep \& Regets, 1999).

\subsection{Translation of Credentials}

Many migrants struggle with the translation of their degrees to those of the receiving society. The process of translation can take considerable time and effort, and usually starts before the arrival of the migrants in their destination. There are a variety of brokers who assist in this process. Employment agencies and institutions in the origin country may play a very important role, especially for medical professionals. Frequently, arrangements may vary depending on the destination of interest and employers are thought to carry great responsibilities in assisting the process. In practice, however, the burden of adaptation usually falls on the migrant as receiving society employers often insist on language competence, and the migrant who is unable to perform a task to the optimal level risks de-skilling. The most common solution adopted is to offer migrants language courses that will facilitate degree translation (CEDEFOP, 2011). However, provisions for such courses vary across countries. In Britain, for example, the cost of language courses offered as English for Speakers of Other Languages (ESOL) is covered by employers (Department for Business, 2010).

In Germany, language courses for migrants are less related to the employment sphere but are part of broader integration courses in which foreign-born people can take 60-hour classes in German culture and politics, and 600 hours of language tuition. Unlike the structured integration courses for the foreign-born population in Germany, there are no similar regulated language courses as part of employment and integration in Italy and Spain. In Italy, migrants are expected to access the information on the job market via local employment offices, and these offices might suggest migrant language courses in their local areas. In Spain, there are Spanish language preparatory courses for foreign-born people, yet these courses are not regulated by authorities, and are not embedded into pathways of informal or formal training. Thus, in many cases, the language preparatory courses do not lead to official qualifications (CEDEFOP, 2011) and fail migrants in the preparation for the main- 
stream labour market. Indeed, the countries in our sample the UK, Germany, Italy and Spain rely much more on the ad-hoc practices adopted by migrants rather than on structured translation of degrees. Examples of the latter can be found in Norway where language courses are mostly part of individualized employment plans and are integrated into job training (CEDEFOP, 2011).

\subsection{Citizenship}

Naturalization is sometimes considered to be the end point in the integration process. Various restrictions on years of residence mean that migrants cannot expect to achieve citizenship in the first few years of their migration journey but at a later stage when they have settled. Nevertheless, naturalization can be part of the integration strategy-it sends strong signals of belonging, of established connections with the receiving society. Thus, employers may also see it as a strong signal, both in terms of permanence of a job candidate and of cultural and linguistic integration. Importantly, the cost of hiring naturalized individuals for receiving society employers can be generally lower as there is no need for checking work permits. The European literature on this topic tends to find small positive 'naturalization premiums' on labour market outcomes, although the effect tends to be heterogeneous and mainly accrues to the most disadvantaged groups (Corluy et al., 2011; Helgertz, Bevelander, \& Tegunimataka, 2014; Jarreau, 2015). Jarreau (2015) studies the effect of naturalization on earnings in France and finds a positive effect due to migrants moving to better-matched jobs after naturalization - an important adaptation strategy for migrants that want to avoid the race to the bottom and improve their positions in general. Previous studies found that migrants that have more to lose are more likely to naturalise (Vink, Prokic-Breuer, \& Dronkers, 2013) - that is to say, highly-skilled migrants who are secure in their positions may find it less of an imperative to naturalize. However, it is likely that adverse climate of reception in the destination, for example Brexit, can give rise to fears of precarity and encourage migrants to undertake steps to regulate their status.

\section{Dataset and Methods}

The GEMM study referenced in this special issue employed a quota design, in some cases oversampling actual migrants with a specific focus on highly skilled migrants to include IT professionals and medical practitioners as well as recruitment agencies personnel. The GEMM sample focused on EU migrants but small sub-set of interviews with US and Chinese highly-skilled migrants in Germany and the UK were included too. More information about the study and its design has been given in the Introduction to this thematic issue.

\section{Findings}

\subsection{Language, Ethnic Niches, and Interactions with 'the Locals'}

The migrants in the GEMM study recognized the importance of language as facilitator of integration however, there were important differences by skill level and occupation of our respondents. Not speaking the language of the receiving society presents a barrier to access of its institutions and to seeking help and support from majority members. Moreover, towards achieving better wellpaid positions may depend upon acquiring fluency. In our sample, the medical professionals who are highly-skilled have made a conscious investment in proficiency courses before they embarked on their respective journeys. They reported the highest levels of pre-migration language competence. This investment in the receiving societies' language is often seen as "absolutely fundamental" and "necessary" in their case as medical professionals can be blocked from practice if they do not have good command of the language of the receiving society. Medical professionals who chose UK as their destination reported having much easier time in terms of language, as English has become the standard second language in many countries around the world. In contrast, medical practitioners migrating to Germany, Italy and Spain had to rely on the help of intermediaries such as employment agencies who would facilitate their enrolment in language training schemes. For example, an Italian recruiter from a private employment agency for health professionals in Naples explained the process:

In the best German university polyclinics, we are forced to offer standards of language higher than others, which we can only achieve by having an intensive language course directly in Germany with board and lodging, where the 8-hour daily study program is accompanied by a daily integration with the German people (attendance of local centres, daily life immersion, shopping). Only in this way can we achieve satisfactory results in terms of language which is always very difficult for Italians. All these costs are financed by the hospitals that at their discretion can give this program completely for free to the candidate or request a $50 \%$ refinancing from the moment that work has started. It is the hospitals that choose the candidates directly through a real contest with an oral interview that takes place "face to face" in our Neapolitan office. (Italian recruiter in a private recruitment agency in Naples)

Not all highly-skilled individuals in our sample however felt the imperative to achieve fluency in the language of the receiving society. Moreover, they did not consider it particularly important in order to be successfully integrated. There are a variety of studies which focus on transnational elites (Beaverstock, 2005; Ryan \& 
Mulholland, 2014) and find that highly-skilled individuals working in the finance sector can secure a very well-paid position in a receiving society while having limited interactions in its language. Similarly, in this study, we find that respondents in the IT and finance sector in Germany do not necessarily use German but rely on English for their socialization and job practice. This can however be very much a Berlin effect (our main data collection site in Germany). Respondents were however well-aware of this exceptionalism. Some respondents however regretted living in such linguistic isolation that provides little opportunity for mastering another language:

After two years of being here...the thing that I regret the most is, I should have tried immediately...personally not having learned German, because in our work we speak only English, which was enough for me. (Italian, banker in Berlin)

In contrast, many of the low-skilled workers did not have any language training or preparation before they set on their respective journeys. Sometimes this was because the migrants did not consider language fluency to be an essential requirement in the sector in which they were seeking employment (particularly in the domestic sector or construction in which a worker can perform tasks under the supervision of a co-national). Often, the migrant has stated that they think learning the language is a good idea but did not receive any help from institutions they considered important gatekeepers or facilitators in their integration journey in the destination. Examples of such facilitators which are failing them are consulates and embassies which many of the migrants in our sample considered almost irrelevant to the migration process (although some respondents will still seek affiliation with such institutions for cultural events and opportunities to mix with co-nationals). Usually the low-skilled migrants depend upon immersing themselves linguistically once they reach their destination even though this may come with challenges as the previous sections showed:

If they offer me [a job], right, I repeat myself, something secure, I shall learn it. It's not something impossible. (Bulgarian in Spain, working in an electronic factory)

I was hired without knowing the language, a Bulgarian woman recommended me. If someone who is sure of you, recommends you, they will hire you. Otherwise, no one will take you directly from the street. They will not even run the risk of talking to an agency. Where I am it is all like that. (Bulgarian domestic cleaner in Spain who shared that she does not use Spanish very often but for when she goes to the school meetings of her children where she is always assisted by other Bulgarian mothers)
Our interviews highlight the importance of the ethnic niche especially for first time arrivals. The literature is almost always split on whether the ethnic economy has positive or negative effects on migrants' incorporation in their destination (Koopmans, 2016; Portes, 1995; Zhou, 1999). On the one hand, seeking employment in a Spanish or Italian café or restaurant in which the manager is a co-national may ensure that the migrant is kept active and employed, and duration of unemployment is minimized (Portes \& DeWind, 2008). Migrants in our sample often relied upon co-ethnics especially in the lowskilled sector in the initial months and years of arrival and spoke openly of the invaluable support provided by the co-ethnic community. Both set of migrants, EU and nonEU, highly and low-skilled sought to embed themselves in various circles of support and make the migration journey less individualistic especially in the first few months. In fact, many migrants said that they moved to a location because of "friends," or "relatives" that could help them find a job:

The first months you don't know the language until you learn it. Well, I came across these two Bulgarian women where I went to the language school and I sat next to them. I constantly asked them questions: How do you pronounce this word and that? And they were explaining everything to me, these two women. And gradually, gradually, with the textbook which I bought in Bulgaria...gradually I got used to the new language. But I was just so stressed. You don't know anything at first. Everybody only speaks Spanish. You don't understand anything at first. (Bulgarian carer, Spain)

I had this conversation with a friend from my hometown working here in Madrid. After some time, I asked him, "Is it possible for me to come to work at this company where you work as a driver?" and he replied, first, "you go through construction, you have to move sacks of garbage, etc." But he helped me, this acquaintance from my hometown, and for several years, two, three years, I worked in construction. And then I went to an interview and started working as a truck driver. (Bulgarian driver in Spain)

At the same time, migrants feared the linguistic isolation from the mainstream that the niche imposes-a frequently cited negative effect (Koopmans, 2016)-as well as a future confined to low-skilled low-paid jobs with great turnover and potential loss of social standing (Favell, 2001; King \& Lulle, 2016). A Romanian programmer in Spain below reflects poignantly on feeling as an outsider both among co-ethnics and among coworkers-a very difficult situation that he felt he could not overcome until he gained fluency in Spanish because then he had more options to choose from:

It was quite difficult at first, because I did not even know any Spanish when I got there, I could barely 
say hola to greet the world. They speak almost exclusively in Spanish, they do not use English [at his place of work], only in discussions with external clients, which was my responsibility, and it was quite difficult for me to get used to and integrate myself in the first four, six months until I started talking, not because they were cold people, but simply because they did not understand me....Like most migrants in Spain, we all socialize the most with our people, with the Romanians there. There was a lot of trouble because, from the point of view of my education and the way I am, I did not like to mix, as it were, with the other Romanians. Most of the Romanians who are in Spain are working and working in fields that do not require very high knowledge or very extensive training in any field, work on planting, working in agriculture very much. Therefore, the kind of people were simple people with whom one could not talk too much. Not that I had something against them, we simply did not have many points of common interest and discussion in general, and then this was a very difficult period for me.... could not speak to the Spaniards very well because I did not know the language or the ones like me because I did not have much to say to them. So, until I started learning it was a bit difficult. I did not have much trouble because of this, I was not in any way discriminated either by my employers or by my fellow men, by my co-nationals, but it was a hard period for me. (Romanian programmer in Spain)

Furthermore, negative interactions with local mainstream institutions can be prevalent especially in the initial stages of the migration process, and the role of the coethnic community in minimizing these can be significant. Many migrants in our sample worried that even when they spoke the local language, they had a strong accent that would immediately mark them as outsiders. There was fear that the mainstream officials would respond to their requests for information in a condescending manner, and although local municipalities were considered efficient brokers of information, they were also largely approached with apprehension, especially during unemployment spells:

Here [in Berlin] I feel a little bit more breath on the neck from the state. This, yes. Then however, from a human point of view, it is not nice-you can expect little empathy from them. (Italian in Germany, an accountant)

Highly-skilled migrants will be more likely to directly approach employers, and for both low and highly-skilled job seekers the next step on the employment ladder involved direct application especially after some years spent in the destination country when it was felt they had become less dependent upon predatory agencies and institutions.
I really think that in an agency you are exploited, that you show, you do not trust your own strength. How do you think I found my job-I have been to hundreds of interviews of course until I've found a job, and I learned next time they will ask me I can tell them myself, that's what I'm interested in and these are the courses I am doing. (Romanian construction worker in the UK)

Sometimes, the mainstream institutions that migrants, especially lower skilled migrants will approach would have a charitable mission such as CARITAS-the charity focusing on combating poverty around the world or churches (contacted by a Bulgarian migrant in the initial stage of the migration process) both of which will be expected to be staffed with caring and understanding locals or with co-nationals (defined broadly sometimes even regional allegiances were mentioned) who would be less likely to judge and patronize. A Bulgarian nurse in the UK described a well-established network revolving around the local parish church which will have Central and Eastern Europeans helping others from the region, especially older migrants who would have difficulties accessing the internet.

Often migrants that could speak the language of the receiving society described a great cultural shock emanating from the perceived lack of care from locals, and perceived lack of empathy towards the migrant who had not yet acquired the insider knowledge and felt disorientated. These points of view are particularly important when we consider integration as a two-way process for which members of the receiving society are as responsible as migrants themselves.

I was waiting for the bus. I was in Leipzig and I was waiting for the bus to return to Berlin. Since there is no real bus station, there are buses lined up along the sidewalk. There is obviously the manager of Flixbus. I go there and tell her, "Excuse me, I have to take the bus to Berlin", and she says, "Okay, you have to stay here." But I see that my bus does not arrive or, in any case, I don't seem to see any bus with the words "Berlin." After a while, a lot, I go to her and I say, "Excuse me, but where is my bus?" And she says, "Eh, didn't you see that it left?" So...l'm angry. "But, sorry, if I showed you my ticket, I told you I have to go to Berlin and you're in front of me and there's a bus in front of you, why don't you tell me: look, this is your bus, even though it says Karlstadt?" An Italian would have told you, that is, an Italian would have even asked you, "What are you going to do in Berlin? Do you have relatives? Do you have friends?" That is, he would have talked to you but really talked. (Italian accountant in Germany)

In contrast, the experience of non-EU migrants was qualitatively different from that of EU migrants. The nonEU migrants in our sample, by sampling design, were 
more likely to be highly-educated (medical professionals, IT and financial sector professionals - with language requirements more relaxed in the case of the latter). In general, they seemed less engaged with the ethnic niche, while still having a variety of experiences of trying to 'make it' in the receiving context-through mainstream school groups, professional bodies that will facilitate the migration and adaptation process. Usually the role of conationals was mentioned last-in many cases, they were potential customers rather than gate keepers and brokers of information. Our sample of non-EU nationals is however very small. Since they are predominantly from the US or Chinese, the geographical distance from the home country can also reinforce potential isolation from co-nationals:

As a translator, the resources I used were just [I relied on myself].... Obviously, I had an office set up with computer, paper and all that. That was just a matter in touch with translation agencies and having them to send me work. And that was never ending. I didn't have to join any associations or anything. In my practice, the most difficult thing was passing the Heilpraktiker exam because it is in German and I had to relearn everything in German and I haven't....I mean I had been out of school since the end of the sixties. So, I had to organize schooling. It took me going to two different schools before I found one good enough to get me through the test. And for the bureaucracy, that wasn't all that bad. It just costs quite a bit of money to get the licensing. Here in the city I live, it is pretty expensive. And, you know, I just started in January. I just joined the...a couple unions, the Heilpraktiker union, I joined the chiropractic association and I am starting to make some contact with other chiropractors and making contact with the Americans here. And...I guess organizing it and getting it going is just a matter of finding office space and being able to afford all the start-up costs, but bureaucracy there wasn't really much of a problem. I just had to send a letter and say that I was opening a practice on a certain date and time and pay the fees. (US nurse in Germany working as a chiropractor)

\subsection{The Translation of Degrees and Educational Credentials}

In the cases of the medical professionals in our sample, almost invariably some translation of degrees has happened prior to the arrival. Several stages are involved in the process of acquiring the right certification. In the first instance, the authority that has issued the degree is contacted (usually a Ministry of Education or a professional association), and bi-lateral agreements with the destination country for the recognition of credentials are discussed. The right of free practice involves sometimes not a small feat of obtaining a variety of documents certifying that the individual does not have a criminal record and has not been charged for misconduct. Only upon obtaining these documents the migrant can register with professional bodies in the destination. These barriers can easily result in deskilling for the migrants as found in other studies (King \& Lulle, 2016) since eager to work individuals without the means to wait may start working at any job to pay off the cost of the migration journey. Employment agency experts are sometimes important brokers in these exchanges, and although they may claim a fee that is considered to be an important step in the migrant adaptation and for securing a good job. Some migrants really fear the bureaucracy in their country of origin, the system of bribes (see other articles in this special issue) that frequently bring dissatisfaction with the country of origin and sets them on the migration journey in the first place:

The procedure in Italy before leaving was scary. There have been many problems. Nobody knew how to help me; what the steps I had to take [were]. Basically, I had to translate my degree certificate into English. [I had to get] someone to translate it in a legal way. And then this translation had to be recognized, so the prefect had to put a stamp. For these two, three steps it took a couple of months....I went around the various offices [to understand what I had to do]. (Italian midwife in the UK)

I had to wait for the validation of my health practitioner title from a [Medical Board], which would be a sort of institute which would give me the validation, could certify the fact that I was eligible to work abroad in London. The only problem was that I prepared all the papers I needed for the validation of the title, and then tried to validate them in Italy, spending money on translations and all else, notary translations and so on, the fact is that once I arrived in London the documents however, they were not valid, they had found problems with my notary translation. So initially I worked as a dishwasher in a restaurant to be able to support myself and not ask for anything at home, after three months, I looked for and waited for post to arrive from home with my documents, but they were not sent. I decide to go directly to the office [back in Italy], and in the office they tell me that my documents had not been processed. Nothing [you can do] - I make sure to receive them again so that they can be validated in London, then I turned to an agency spending more money to have the translations certified again, I send them back [to the UK]. It took more than three months. (Italian health care professional working in Germany who has originally found a job in the UK)

A Bulgarian worker described what he thinks of the Bulgarian authorities abroad when he was asked whether he contacted any (he had indeed been wanting to renew a driver's license needed for his work): 
[In Spain] everything happens faster. Now if you go to our embassy [it is much slower]. That's what we, Bulgarians, are. Doesn't matter where we are, we behave as Bulgarians....They simply don't know how they should interact with people. They are always cold; they don't explain [things] to you, you have to guess. (Bulgarian construction worker in Spain)

Decisions to take any work may have considerable impact upon the individual's work trajectory as tenure is a strong signal to employers about the skill and potential of employees. Moreover, a migrant who has already started work may not necessarily have time to prepare for the exams which are part of obtaining the right to work in the UK, Italy and Spain, a further set back in terms of their professional realization and personal life (Ruhs \& Anderson, 2010; Stirling, 2015). The following quotes are from a construction worker and a nurse who have experienced difficulties and talk of the stress of working long hours:

At the beginning I didn't know German at all! The job does not allow you to learn, you know the times that I keep from seven am to four pm, you have to go home, and I also helped my family. My wife did the German school in the evening. (Italian construction worker in Germany)

In my current job situation, I have no problem at all. But if you say "previous job," in which I worked in ward, and worked twelve hours a shift, there is conflict...hum, not from me, but I do observe in other colleagues. Maybe, due to long hour[s]? The workload? People are very tired. Maybe family? Yeah. There is tension, conflict occurring in work more often. (nonEU nurse based in the UK that started as a nurse in an emergency ward)

\subsection{Citizenship}

Unlike previous research (Graeber, 2016) which has suggested that EU migrants from less well-to-do European countries might strive to acquire the citizenship of more well-off countries, there is little in our data to support such a conclusion, even for less skilled migrants who should be in more precarious positions:

I've been asked this a lot, why I haven't taken up German nationality. But why would I? I'm in the European Union and I don't feel German. (Spanish accountant in Germany)

I've never felt the urge [to get foreign citizenship]. For what? At one time, some people...it was the fashion to come here [Italy], you have researched the conditions for Italian citizenship, the more advantages you have [if you had one]. I have, since we entered the European Union, the benefits for all. Why should I need the superfluous Italian citizenship? Dual
citizenship-I don't need it, I have Italian documents for my stay in Italy while sitting here, I can give you an ID card and that's it. I don't want an Italian passport. What's wrong with mine? I have a Bulgarian passport. End of story. (Bulgarian driver in Italy)

In countries, perceived to be in crisis however there were conflicting views. Brexit did scare some and in particular put into question their ability to vote and participate in the social life of the country, thus becoming a turning point for many (Finotelli, La Barbera, \& Echeverría, 2018):

Yes, yes, why not? Especially if they [Britain] leave Europe, it is useful. (Italian Investment banker in the UK)

I think it is the right thing to do, to get the citizenship of the country where you pay taxes, so you can participate in the national elections. I have an interest in the political life here, and yes, I think that there comes a time when dual citizenship is such a natural development of things when you have lived for many years in one place. (Bulgarian IT specialist in the UK)

Citizenship can be considered strategically useful in an increasingly hostile environment where many feared direct attacks although perceived increase in negative feelings brought about a sense of despondency and pessimism:

[When prompted about the impact of Brexit] It depends on what will be negotiated. Depending on their negotiations, you know that racial attacks against Romanians and other Europeans have increased. Even yesterday there was a case, a Polish [guy] was attacked on the subway. (Romanian dentist in the UK)

We talked about Brexit. Even at work, there were some people who just spoke very negatively [about foreigners], you know, telling you-just a passport won't make you that nationality and probably you will never be [British]. (Bulgarian construction worker describing some of the disadvantages of living in the UK)

Non-EU nationals also had mixed feelings towards citizenship and the need of acquiring citizenship. Compared to EU nationals, they also perceived a much greater need of brokers that will facilitate the process for them:

I have only one citizenship, and that's American, I probably will get my British citizenship though, I am eligible for it, I just need to fill in the paperwork or hire a law firm to do it. (US software company employee working in the UK)

\section{Discussion}

This study highlighted the variety of adaptation strategies of migrants in the four countries of destination. 
Similarly to previous studies we note that highly-skilled migrants are much more likely to invest in acquiring human capital typical for the receiving society that will guarantee them freedom to work. However, our interviews show that eventually most migrants do catch up. Working long and unsociable hours does not encourage low-skill workers to integrate socially and they are on average confined to ethnic niches and to jobs with little prospects of professional development for longer periods of time.

Many migrants, especially professionals start the process of acclimatization long before they set on their respective migration journeys. They can seek further assistance from agencies such as EURES which facilitate the exchange of ideas at the inter-European level however all the voices in our interviews point to insufficient or ineffective institutional support. The non-EU migrants in our sample also depend on a variety of professional bodies that aid highly-skilled foreign workers but in general had the confidence and resources to approach directly a variety of different institutions and employers. It appears that there is much need for a unified system that assist migrants with their work requirements and the translation of credentials.

Although low-skilled migrants may not have the desire to remain in linguistic isolation, some of them are forced to do so by the nature of their employment in ethnic niches. Migrants also physically concentrate in less desirable areas as they are cheaper, and they can afford the housing. Whereas studies differ on whether they are pushed in such areas out of their own choice (e.g., Semyonov \& Glikman, 2009), or because of housing discrimination (e.g., Boeri, De Philippis, Patacchini, \& Pellizzari, 2015), the result is the same-a set of limited opportunities for acquiring skilled jobs and professional development of which disadvantage migrants are painfully aware. Indeed more work should be done on whether ethnic niches shield migrants from potential discrimination (see, e.g., Bécares et al., 2011; Nandi \& Platt, 2015). The provision of ethnic goods and positive social and cultural connections at the ethnic enclave, as well as labour advice should not be underestimated (Portes \& Zhou, 1993; Zhou, 2005). Yet, areas that are often more deprived also offer fewer opportunities (Feng, Flowerdew, \& Feng, 2015). The migrants in our sample harbour dreams of better jobs and moving to nicer areas that might however take some years to be realized if ever. Linguistic English bubbles were also common among transnational elites working in the finance and IT sector. Importantly, citizenship was something that not all migrants considered, and the rates of reported naturalization were relatively low among EU migrants even with Brexit looming.

\section{Acknowledgments}

I would like to thank my GEMM project colleagues who were responsible for the collection of the GEMM data and the preparation of various reports based on it-Siyka Kovacheva (an excellent leader of the qualitative data work package), Boris Popivanov, Plamen Nanov, Radka Peeva, Dorel Abraham, Octav Marcovici, Marin Burcea, Ionela Sufaru, Iraklis Dimitriadis, Giovanna Fullin, Diego Coletto, Fabio Quassoli, Maricia Souan-Fischer, Javier Polavieja, Alexandra Pop and Thomas Tichelbaker. This article was written as part of the output of the EU Horizon 2020 GEMM Project (Grant agreement no. 649255).

\section{Conflict of Interests}

The authors declare no conflict of interests.

\section{References}

Beaverstock, J. V. ( 2005). Transnational elites in the city: British highly-skilled inter-company transferees in New York city's financial district. Journal of Ethnic and Migration Studies, 31, 245-268.

Bécares, L., Stafford, M., Laurence, J., Nazroo, J. (2011). Composition, concentration and deprivation: Exploring their association with social cohesion among different ethnic groups in the UK. Urban Studies, 48(13), 2771-2787.

Bevelander, P., \& Pendakur, R. (2014). The labour market integration of refugee and family reunion immigrants: A comparison of outcomes in Canada and Sweden. Journal of Ethnic and Migration Studies, 40, 689-709.

Boeri, T., De Philippis, M., Patacchini, E., \& Pellizzari, M. (2015). Immigration, housing discrimination and employment. The Economic Journal, 125(586), F82-F114.

Campbell, S. (2014). Does it matter why immigrants came here? Original motives, the labour market, and national identity in the UK (DQSS Working Paper). UCL Institute of Education, London.

Cangiano, A. (2015). Migration policies and migrant employment outcomes. Comparative Migration Studies, 2, 417-443.

Cebulla, A., Daniel, M., Zurawan, A., Brown, V., Tipping, S., \& Tomaszewski, W. (2010). Spotlight on refugee integration: Findings from the survey of new refugees in the United Kingdom (Research Report 37). London: Home Office and UK Visas and Immigration.

CEDEFOP. (2011). Employment-related mobility and migration, and vocational education and training (Working Paper 9). Luxembourg: Publications Office of the European Union.

Cheung, S. Y., \& Phillimore, J. (2013). Refugees, social capital, and labour market integration in the UK. Sociology, 48(3), 518-536.

Corluy, V., Marx, I., \& Verbist, G. (2011). Employment chances and changes of immigrants in belgium: The impact of citizenship. International Journal of Comparative Sociology, 52, 350-368.

Cortes, K. E. (2004a). Are refugees different from eco- 
nomic immigrants? Some empirical evidence on the heterogeneity of immigrant groups in the United States. The Review of Economics and Statistics, 86, 465-480.

Cortes, K. E. (2004b). Are refugees different from economic immigrants? Some empirical evidence on the heterogeneity of immigrant groups in the United States. Review of Economics and Statistics, 86, 465-480.

de Vroome, T., \& van Tubergen, F. (2010). The employment experience of refugees in the Netherlands. International Migration Review, 44, 376-403.

Department for Business. (2010). Skills for sustainable growth: Strategy document. UK Government. Retrieved from https://www.gov.uk/government/ publications/skills-for-sustainable-growth-strategydocument

Duleep, H. O., \& Regets, M. C. (1999). Immigrants and human-capital investment. American Economic Review, 89(2), 186-191.

Dustmann, C., Frattini, T., \& Halls, C. (2010). Assessing the fiscal costs and benefits of A8 migration to the UK. Fiscal Studies, 31, 1-41.

Favell, A. (2001). Philosophies of integration: Immigration and the idea of citizenship in France and Britain. Basingstoke: Palgrave.

Feng, X., Flowerdew, R., \& Feng, Z. (2015). Does neighbourhood influence ethnic inequalities in economic activity? Findings from the ONS Longitudinal Study. Journal of Economic Geography, 15(1), 169-194.

Finotelli, C., La Barbera, M., \& Echeverría, G. (2018). Beyond instrumental citizenship: The Spanish and Italian citizenship regimes in times of crisis. Journal of Ethnic and Migration Studies, 44, 2320-2339.

Friedberg, R. M. (2000). You can't take it with you? Immigrant assimilation and the portability of human capital. Journal of Labor Economics, 18, 221-251.

Graeber, J. (2016) Citizenship in the shadow of the Euro crisis: Explaining changing patterns in naturalisation among intra-EU migrants. Journal of Ethnic and Migration Studies, 42, 1670-1692.

Helgertz, J., Bevelander, P., \& Tegunimataka, A. (2014). Naturalization and earnings: A Denmark-Sweden comparison. European Journal of Population, 30, 337-359.

Jarreau, J. (2015). The impact of naturalizations on job mobility and wages: Evidence from France (AMSE Working Paper No. 1508). Marseille: Aix Marseille School of Economics.

Kaufmann, E., \& Harris, G. (2015). "White Flight" or positive contact? Local diversity and attitudes to immigration in Britain. Comparative Political Studies, 48, 1563-1590.

King, R., \& Lulle, A. (2016). Research on migration: Facing realities and maximising opportunities (Policy Review Report). Luxembourg: Publications Office of the European Union.

Kogan, I., \& Shen, J. (2019). It's the economy! Perceptions of host-countries' institutions and individual life satisfaction of intra-European migrants. Frontiers in Sociology, 4(42), 1-16.

Kogan, I., Shen, J., \& Siegert, M. (2018). What makes a satisfied immigrant? Host-country characteristics and immigrants' life satisfaction in eighteen European countries. Journal of Happiness Studies, 19(6), 1783-1809.

Kogan, I., Kalter, F., Liebau, E., \& Cohen, Y. (2011). Individual resources and structural constraints in immigrants' labour market integration. In M. Wingens, M. Windzio, H. de Valk, \& C. Aybek (Eds.), A lifecourse perspective on migration and integration (pp. 75-101). Dordrecht: Springer.

Koopmans, R. (2016). Does assimilation work? Sociocultural determinants of labour market participation of European Muslims. Journal of Ethnic and Migration Studies, 42(2), 197-216.

Luthra, R., Platt, L., \& Salamońska, J. (2016). Types of migration: The motivations, composition, and early integration patterns of "new migrants" in Europe. International Migration Review, 52(2), 368-403.

Nandi, A., \& Platt, L. (2015). Patterns of minority and majority identification in a multicultural society. Ethnic and Racial Studies, 38(15), 2615-2634.

OECD. (2017). International migration outlook 2017. Paris: OECD Publishing.

Portes, A. (1995). The economic sociology of immigration: Essays on networks, ethnicity and entrepreneurship. New York, NY: Russell Sage Foundation.

Portes, A., \& DeWind, J. (2008). Rethinking migration: New theoretical and empirical perspectives. New York, NY: Berghahn Books.

Portes, A., \& Zhou, M. (1993). The new 2nd-generation: Segmented assimilation and its variants. Annals of the American Academy of Political and Social Science, 530, 74-96.

Ruhs, M., \& Anderson, M. (2010). Who needs migrant workers? Labour shortages, immigration, and public policy. Oxford: Oxford University Press.

Ryan, L., \& Mulholland, J. (2014). French connections: The networking strategies of French highly skilled migrants in London. Global Networks, 14, 148-166.

Semyonov, M., \& Glikman, A. (2009). Ethnic residential segregation, social contacts, and anti-minority attitudes in European societies. European Sociological Review, 25(6), 693-708.

Stirling, A. (2015). Migrant employment outcomes in European labour markets. London: IPPR.

Vink, M. P., Prokic-Breuer, T., \& Dronkers, J. (2013). Immigrant naturalization in the context of institutional diversity: Policy matters, but to whom? International Migration, 51, 1-20.

Zhou, M. (1999). Segmented assimilation: Issues, controversies and recent research on the new second generation. In C. Hirschman, J. Dewind, \& P. Kasinitz (Eds.), The handbook of international migration: The American experience (pp. 196-212). New York, NY: Russell 
Sage Foundation.

Zhou, M. (2005). Ethnicity as social capital: Communitybased institutions and embedded networks of social relations. In G. C. Loury, T. Modood, \& S. M. Teles (Eds.), Ethnicity, social mobility and public policy (pp. 131-159). Cambridge: Cambridge University Press.

\section{About the Author}

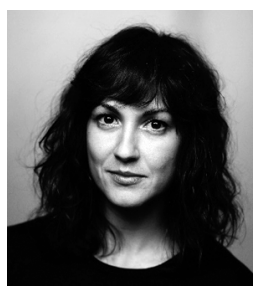

Neli Demireva (PhD) is a Senior Lecturer in Sociology at Essex University. Her research interests include migration, inter-ethnic ties, social cohesion, ethnic penalties and multiculturalism. 